\title{
MAJOR-OXIDE AND TRACE-ELEMENT GEOCHEMICAL DATA FROM ROCKS COLLECTED NEAR PANORAMA MOUNTAIN, MILE 104 SEWARD HIGHWAY, CROW PASS, AND WHITTIER, ALASKA \\ Lawrence K. Freeman, Simone Montayne, and Alicja Wypych
}

Raw Data File 2017-12

This report has not been reviewed for technical content or for conformity to the editorial standards of DGGS.

December 2017

State of Alaska

Department of Natural Resources

Division of Geological \& Geophysical Surveys

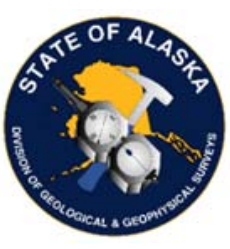




\section{STATE OF ALASKA \\ Bill Walker, Governor}

DEPARTMENT OF NATURAL RESOURCES

Andrew T. Mack, Commissioner

DIVISION OF GEOLOGICAL \& GEOPHYSICAL SURVEYS

Steve Masterman, State Geologist \& Director

Publications produced by the Division of Geological \& Geophysical Surveys are available to download from the DGGS website (dggs.alaska.gov). Publications on hard-copy or digital media can be examined or purchased in the Fairbanks office:

Alaska Division of Geological \& Geophysical Surveys (DGGS)

3354 College Road | Fairbanks, Alaska 99709-3707

Phone: $907.451 .5010 \mid$ Fax 907.451.5050

dggspubs@alaska.gov | dggs.alaska.gov

DGGS publications are also available at:

Alaska State Library, Historical

Collections \& Talking Book Center

395 Whittier Street

Juneau, Alaska 99801

Alaska Resource Library and

Information Services (ARLIS)

3150 C Street, Suite 100

Anchorage, Alaska 99503

\section{Suggested citation:}

Freeman, L.K., Montayne, Simone, and Wypych, Alicja, 2017,

Major-oxide and trace-element geochemical data from rocks

collected near Panorama Mountain, Mile 104 Seward Highway,

Crow Pass, and Whittier, Alaska: Alaska Division of Geological \&

Geophysical Surveys Raw Data File 2017-12, 4 p. http://doi.org/10.14509/29725

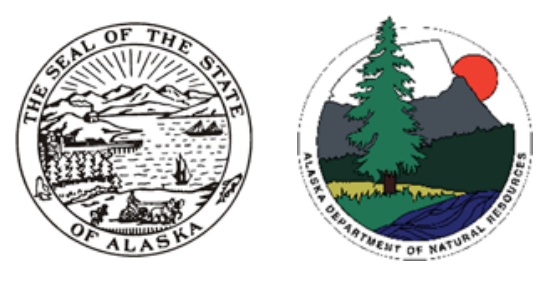




\section{MAJOR-OXIDE AND TRACE-ELEMENT GEOCHEMICAL DATA FROM ROCKS COLLECTED NEAR PANORAMA MOUNTAIN, MILE 104 SEWARD HIGHWAY, CROW PASS, AND WHITTIER, ALASKA}

Lawrence K. Freeman'1, Simone Montayne ${ }^{2}$ and Alicja Wypych ${ }^{2}$

\section{INTRODUCTION}

In conjunction with hosting field trips for the Association of American State Geologists 2016 annual meeting in Girdwood, Alaska, Alaska Division of Geological \& Geophysical Surveys (DGGS) staff collected rock samples and obtained geochemical analysis from several readily accessible, but relatively unstudied outcrops. Samples were collected from Turnagain Arm (mile 104 Seward Highway), Whittier, Crow Pass, and Panorama Mountain (roughly mile 217 Parks Highway). Mineralized samples from veins and veinlets in granitic rocks from the Crow Pass and Whittier sites contain anomalous levels of gold ranging from 0.129 to 0.650 parts per million (ppm). Although none of the samples are from areas open to mineral entry, geochemical analyses of rocks from these localities may support interpretation of regional mineral-distribution trends.

The analytical data tables associated with this report are available in digital format as comma-separated value (CSV) files. Additional details about the organization of information are noted in the accompanying metadata file. All files can be downloaded from the DGGS website (http://doi.org/10.14509/29725). The samples and pulps are stored at the Alaska Geological Materials Center in Anchorage.

\section{GEOLOGIC CONTEXT}

\section{Turnagain Arm, approximately mile 104 Seward Highway}

Sample 16LF001A was collected from the north side of Turnagain Arm in turbidities exposed in wave-washed outcrops between normal high tide line and base of railroad rip-rap, roughly 150 meters west of Indian Creek. The sample was extracted from a felsic dike belonging to the Sanak-Baranof near-trench intrusive suite (Karl and others, 2011).

\section{Whittier roadcut}

Three samples (16LF002A, 16LF002B, 16LF002C) were collected from a road-cut exposure near Whittier, Alaska. The samples were obtained from a felsic dike near the west end of the outcrop along the south side of the railroad, between Whittier and the tunnel portal. This dike intrudes the argillite-rich part of the Valdez Group and it is inferred to be associated with

\footnotetext{
${ }^{1}$ Alaska Division of Geological \& Geophysical Surveys, retired 2016

${ }^{2}$ Alaska Division of Geological \& Geophysical Surveys, 3354 College Road, Fairbanks, Alaska 99709-3707
} 
the gold- baring Sanak-Baranof suite (Karl and others, 2011).

Sample 16LF002C, which is from a pyrite- and galena-bearing vein not previously documented in public literature, yielded a gold value of $0.650 \mathrm{ppm}$. Samples 16LF002A and 16LF002B yielded gold values of $0.022 \mathrm{ppm}$ and $0.129 \mathrm{ppm}$, respectively. ${ }^{40} \mathrm{Ar} /{ }^{39} \mathrm{Ar}$ analyses of these two samples yielded ages of 53.0 $\pm 0.3 \mathrm{Ma}(16 \mathrm{LF} 002 \mathrm{~A})$ and $50.9 \pm 0.2 \mathrm{Ma}$ (16LF002B) (Benowitz and others, 2017).

\section{Crow Pass}

Sample 16LF003A was collected from sheeted quartz veinlets in a granitic stock intruding Valdez Group rocks exposed along the Crow Pass hiking trail in the Chugach Mountains (Clark and Yount, 1972). The stock is one of several small intrusions interpreted to be related to ridge subduction in south-central Alaska's Mesozoic accretionary prism (Haeussler and others, 1995). Mines, including Jewell, Brenner, and Agustino (Alaska Resource Data File AN107, AN108, and AN 109) in the Crow Pass area produced nearly 5,000 ounces of gold from polymetallic quartz veins in Valdez Group country rock (U.S. Geological Survey, 2008). The assay value for this sample was 0.201 ppm gold.

\section{Panorama Mountain}

Sample (16LF004A) was collected from a borrow pit near Panorama Mountain, in the central Alaska Range. Panorama Mountain is composed of metamorphosed mafic rocks in a tectonic wedge north of the Denali Fault. Reconnaissance geologic mapping (Jones and others, 1983; Csejtsey and others, 1992) assign the meta-mafic rocks to Upper Triassic and associate them with Triassic to Pennsylvanian flysch. Together the meta-mafic rocks and flysch comprise the McKinley Terrane (Jones and others, 1981; Jones and others, 1983). However, subsequent compilations assign the meta-mafic rocks to the Upper Triassic Nikolai Greenstone and the Wrangellia terrane (Wilson and others, 1998). Prior to this report, no lithogeochemistry has been published from Panorama Mountain meta-mafic rocks.

\section{DOCUMENTATION OF METHODS}

\section{Sample collection}

Rock samples were collected for two different purposes. First, samples of visibly mineralized or altered rock were preferentially collected and analyzed for trace-element geochemistry. Second, igneous rocks showing little alteration or weathering were collected for whole-rock major-oxide, minor-oxide, and trace-element analyses to aid in classification and study of petrogenesis and tectonic setting. All samples presented in this reports are 'select' samples, which were more deliberately collected from a specific feature, as noted in the sample field description.

Location data were collected using a Nexus 5x smartphone operating the Avenza Maps 
2.0 Application (AvenzaMaps.com). Location error for this application is undocumented, however, locations were visually checked using USGS and multiple imagery files in ArcGIS and errors are estimated to be within 20 meters. Latitude and longitude are reported in the WGS84 datum.

\section{Sample preparation}

Rock samples were processed by ALS Geochemistry using their PREP-31 package. The samples were crushed to greater than 70 percent passing $2 \mathrm{~mm}$, and a 250 -gram (g) split was pulverized to greater than 85 percent passing 75 microns. Prior to crushing, samples for wholerock analysis were trimmed by DGGS staff to remove weathering, and cut surfaces were sanded to remove any saw metal.

\section{Analytical methods}

Samples were analyzed for a variety of major and trace elements depending on the sample type. In addition to ALS Geochemistry's accredited (ISO/IEC 17025-2005) internal qualitycontrol program, DGGS monitored analysis quality with one standard reference material per batch of analyses.

A. Major- and trace-element values for rock samples were determined by ALS Geochemistry method ME-MS61: Four-acid digestion followed by inductivelycoupled plasma-atomic emission spectrometry (ICP-AES) and inductively-coupled plasma-mass spectroscopy (ICP-MS); Au values were determined using flux digestion and fire assay and ICP-AES (ALS Geochemistry method Au-ICP21).

B. For whole-rock geochemistry samples, major and minor oxides were analyzed by lithium fusion digestion and ICP-AES (ALS Geochemistry method ME-ICP06). Trace elements, including rare-earth elements, were determined using lithium borate fusion digestion and ICP-MS (ALS Geochemistry method ME-MS81). Ag, Cd, Co, Cu, Li, $\mathrm{Mo}, \mathrm{Ni}, \mathrm{Pb}, \mathrm{Sc}$, and $\mathrm{Zn}$ were determined by four-acid digestion and ICP-AES (ALS Geochemistry method ME-4ACD81); and As, Bi, Hg, In, Re, Sb, Se, Te, and Tl were determined by aqua regia digestion followed by ICP-MS (ALS Geochemistry method ME-MS42). Total C and S were analyzed by Leco furnace (ALS Geochemistry methods C-IR07 and S-IR08, respectively). Au values for Whittier and Turnagain Arm samples were determined using flux digestion and fire assay and ICP-AES (ALS Geochemistry method Au-ICP21). Platinum, palladium, and gold values for the sample collected at the base of Panorama Mountain were analyzed by 30-g fire assay with ICP-MS finish (ALS Geochemistry method PGM-MS23).

In the analytical-data table, field names (column headers) show the element and the units in which they are reported. In the detection-limits table and the metadata file, documentation is provided to explain each field name, as well as additional details such as lab name and method codes, analytical-method types and documentation, and the upper and lower detection limits for 
each of the elements and methods.

For each sample, data tables contain either assay values or coded-value placeholders (null $=$ not analyzed; $-1=$ the element's assay result is less than the lower detection limit for the method). Detection limits for each of the reported elemental values obtained by the various methods are provided in an accompanying table and documented in the metadata file.

\section{ACKNOWLEDGMENTS}

To comply with Alaska Railroad Corporation regulations and safely collect these samples, DGGS staff obtained written permission from the Alaska Railroad Corporation to cross the Right of Way. The sample collection and analyses were supported by State of Alaska general funds. Outcrop locations and geologic information, as well as assistance with the field trips, were provided by Sue Karl (U.S. Geological Survey), Peter Oswald (University of Alaska), and Joe Kurtak.

\section{REFERENCES}

Benowitz, J.A., Layer, P.W., Wypych, Alicja, and Freeman, L.K., 2017, ${ }^{40} \mathrm{Ar} /{ }^{39} \mathrm{Ar}$ ages of rocks collected from the Passage Canal area, Seward D-7 Quadrangle, Alaska: Alaska Division of Geological \& Geophysical Surveys Raw Data File 2017-4, 6 p. http://doi.org/10.14509/29721

Clark, S.H.B., and Yount, M.E., 1972, Reconnaissance geologic map and geochemical analyses of stream-sediment and rock samples of the Anchorage A-6 Quadrangle, Alaska: U.S. Geological Survey Miscellaneous Field Studies Map 351, 2 sheets, scale 1:63,360.

http://dggs.alaska.gov/pubs/id/13148

Csejtey, Bela, Jr., Mullen, M.W., Cox, D.P., and Stricker, G.D., 1992, Geology and geochronology of the Healy Quadrangle, south-central Alaska: U.S. Geological Survey Miscellaneous Investigations Series Map 1961, 63 p., 2 sheets, scale 1:250,000 http://dggs.alaska.gov/pubs/id/12847

Haeussler, P.J., Bradley, D.C., Goldfarb, R.J., Snee, Lawrence., and Taylor, Cliff., 1995, Link between ridge subduction and gold mineralization in southern Alaska: Geology, v. 23, p. 995998.

Jones, D.L., Silberling, N.J., Berg, H.C., and Plafker, George, 1981, Map showing tectonostratigraphic terranes of Alaska, columnar sections, and summary description of terranes: U.S. Geological Survey Open-File Report 81-792, 20 p., 2 sheets, scale 1:2,500,000. http://dggs.alaska.gov/pubs/id/11367

Jones, D.L., Silberling, N.J., Gilbert, W.G., and Coney, P.J., 1983, Tectono-stratigraphic map and interpretive bedrock geologic map of the Mount McKinley region, Alaska: U.S. Geological Survey Open-File Report 83-11, 2 sheets, scale 1:250,000. http://dggs.alaska.gov/pubs/id/12132 
Karl, S.M., Bradley, D.C., Combellick, R.A., and Miller, M.L., 2011, Field guide to the accretionary complex and neotectonics of south-central Alaska, Anchorage to Seward: Anchorage, Alaska Geological Society, 45 p.

U.S. Geological Survey, 2008, Alaska Resource Data File (ARDF): U.S. Geological Survey OpenFile Report 2008-1225.

Wilson, F.H., Dover, J.H., Bradley, D.C., Weber, F.R., Bundtzen, T.K., and Haeussler, P.J., 1998, Geologic map of Central (Interior) Alaska: U.S. Geological Survey Open-File Report 98-133A, 62 p., 3 sheets. http://dggs.alaska.gov/pubs/id/14822 